\title{
Corrigendum
}

Cold Spring Harb Protoc 2014; doi: 10.1101/pdb.prot074963

\section{Corrigendum: Purification of Endothelial Cells from Rodent Brain by Immunopanning}

Lu Zhou, Fabien Sohet, and Richard Daneman

When this article was first published, the recipe entitled "T3 Stock $(4 \mu \mathrm{g} / \mathrm{mL})$," which originally appeared in Dugas and Emery (2013) and Emery and Dugas (2013), contained errors. The quantity and concentration of thyroid hormone (T3) in Step 1 of the recipe were incorrectly listed as $4 \mu \mathrm{g}$ and $0.8 \mu \mathrm{g} / 100 \mu \mathrm{L}$, respectively. The quantity of T3 should be $4 \mathrm{mg}$, and the concentration should be $0.8 \mathrm{mg} / 100 \mu \mathrm{L}$. The authors of the original recipe apologize for these errors. A corrected version of the recipe is below. In addition, the HTML version of the recipe (doi: 10.1101/pdb.rec075507) and the PDF versions of all three articles have been amended accordingly.

\section{T3 Stock $(4 \mu \mathrm{g} / \mathrm{mL})$}

1. Dissolve $4 \mathrm{mg}$ of thyroid hormone (T3; Sigma-Aldrich T6397) in $500 \mu \mathrm{L}$ of $1 \mathrm{~N} \mathrm{NaOH}$ to prepare a solution of $0.8 \mathrm{mg} / 100 \mu \mathrm{L}$.

2. Add $75 \mu \mathrm{L}$ of the T3 solution from Step 1 to $150 \mathrm{~mL}$ of Dulbecco's phosphate-buffered saline (DPBS; Invitrogen 14287-080).

3. Filter solution through a filter-sterilization unit, discarding the first $10 \mathrm{~mL}$.

4. Aliquot (e.g., $200 \mu \mathrm{L} /$ tube) and then store at $-20^{\circ} \mathrm{C}$.

\section{REFERENCES}

Dugas JC, Emery B. 2013. Purification of oligodendrocyte precursor cells from rat cortices by immunopanning. Cold Spring Harb Protoc doi: $10.1101 /$ pdb.prot070862.
Emery B, Dugas JC. 2013. Purification of oligodendrocyte lineage cells from mouse cortices by immunopanning. Cold Spring Harb Protoc doi: 10.1101/pdb.prot073973. 


\section{Corrigendum: Purification of Endothelial Cells from Rodent Brain by Immunopanning}

Lu Zhou, Fabien Sohet and Richard Daneman

Cold Spring Harb Protoc; doi: 10.1101/pdb.corr102962

\begin{aligned} & $\begin{array}{r}\text { Email Alerting } \\ \text { Service }\end{array}$ Receive free email alerts when new articles cite this article - click here. \\ & \hline $\begin{array}{c}\text { Subject } \\ \text { Categories }\end{array}$ Browse articles on similar topics from Cold Spring Harbor Protocols. \\ & \hline\end{aligned}

